\title{
KEMAMPUAN GURU-GURU SEKOLAH DASAR DALAM PEMGEMBANGAN KIT IPA SEDERHANA BERBASIS ALAM SEKITAR SE KECAMATAN INUMAN
}

\author{
Zulhelmi $^{1)}$, Muhammad Nor ${ }^{2)}$, Fakhruddin ${ }^{3)}$ Betty Holiwarni ${ }^{4)}$ \\ ${ }^{1,2,3,4)}$ FKIP Universitas Riau \\ e-mail: emi_zain@yahoo.co.id \\ mnoer_rs@yahoo.com \\ faruqfisika@yahoo.com \\ warniholy@gmail.com
}

\begin{abstract}
Abstrak
Tujuan dari kegiatan pelatihan ini adalah untuk melatih guru-guru Sekolah Dasar (SD) se Kecamatan Inuman Kabupaten Kuantan Singingi mengembangkan komponen instrumen terpadu (KIT) IPA berbasis alam sekitar. Guru-guru dilatih untuk mengoperasikan KIT IPA SD yang telah dikembangkan. Khalayak sasaran adalah guru-guru SD se Kecamatan Inuman Kabupaten Kuantan Singingi dan yang mengikuti kegiatan ini berasal dari perwakilan SD negeri dan swasta dengan jumlah peserta 29 orang guru dari 12 sekolah. Metode kegiatan adalah melalui penyajian materi, pemodelan, pelatihan dan simulasi/diskusi. Evaluasi dilaksanakan mulai dari awal kegiatan, selama pelaksanaan, dan diakhir kegiatan dengan teknik angket, observasi, dan wawancara. Data dianalisis secara deskriptif. Hasil analisis data diperoleh rata-rata kinerja peserta $89 \%$ pada kategori sangat baik, begitu juga respon peserta tentang kegiatan pengabdian ini sebesar 97,5\% pada kategori sangat baik. Kesimpulan dari hasil kegiatan pelatihan ini yaitu guru-guru SD di Kecamatan Inuman Kabupaten Kuantan Singingi memiliki pengetahuan dan mampu mengimplemetasikan dalam mengembangkan KIT IPA sederhana berbasis alam sekitar untuk pembelajaran IPA di SD.
\end{abstract}

Kata Kunci: alam sekitar, KIT IPA, sekolah dasar

\begin{abstract}
The purpose of this training activity is to train the elementary school teachers in Inuman Sub-District, Kuantan Singingi Regency to developing an integrated instrument component (IIC) natural science based on nature around. Teachers are trained to operate the Integrated Instrument Components natural science elementary shool that has been developed. The target audience is elementary school teachers in Inuman SubDistrict, Kuantan Singingi Regency and who attended this event came from public and private elementary school representatives with 29 participants from 12 schools. Method of activity is the presentation of materials, modeling, training and simulation /discussion. Evaluation carried out from the beginning of the activity, during the implementation and the end of activities with questionnaires, observations and interviews. Data were analyzed descriptively. The result of data analysis obtained by the average of the performance of $89 \%$ participants in very good category, so also the participant response about this service activity equal to $97,5 \%$ in very good category. The conclusion of the results of this training activities of elementary school teachers in the Inuman Sub-District, Kuantan Singingi Regency has the knowledge and able to implemeting in developing an integrated instrument component simple natural science based on nature around for natural science learning in elementary school.
\end{abstract}

Keywords: nature around, integrated instrument components natural science, elementary school 


\section{Pendahuluan}

Kendala yang dihadapi dalam pembelajaran IPA di SD adalah kekurangan perangkat praktikum IPA SD karena kenyataannya belum seluruh sekolah di Indonesia yang mempunyai KIT IPA, walaupun ada tetapi guru-guru SD di sekolah tersebut ada sebagian yang belum bisa menggunakannya. Begitu juga KIT IPA yang sudah disediakan pemerintah tersebut lebih banyak bersifat pemodelan, sehingga kegiatan praktikum yang sesungguhnya kurang bisa dilakukan. Hal ini juga terjadi pada saat pelatihan tentang penggunaan KIT IPA berorientasi pendekatan keterampilan proses untuk guru-guru SD di Kecamatan Minas Kabupaten Siak (Zulhelmi, 2013). Masalah yang sama ini pun terjadi di Kecamatan Inuman Kabupaten Kuantan Singingi.

Kecamatan Inuman merupakan salah satu kecamatan yang berada di Kabupaten Kuantan Singingi yang mempunyai jumlah penduduk 15.482 jiwa dengan luas wilayah $453,01 \mathrm{Km}^{2}$ dan terdiri dari $11 \mathrm{desa} /$ kelurahan. (BPS Kuantan Singingi, 2017). Topograpi Kecamatan Inuman merupakan (tanah datar dan berbukit-bukit) dengan ketinggian sekitar 36 meter dari permukaan laut. Jenis tanah yang ada di Kecamatan Inuman pada lapisan atas berjenis (hitam gembur) dan pada lapisan bawahnya berwarna Kuning. Sungai besar yang mengalir di Kecamatan Inuman adalah Sungai Kuantan yang merupakan aliran dari sungai yang ada di propinsi Sumatera Barat, yang bermuara ke Kabupaten Indragiri Hulu. Disamping itu, juga terdapat 3 sungai kecil yang sama-sama bermuara ke sungai Kuantan, yaitu sungai Ili, sungai Human, dan sungai Pemokar. Jumlah SD yang ada di Kecamatan Inuman 16 SD (15 SD Negeri dan 1 SD Swasta). Jumlah guru SD sebanyak 181 orang yang terdiri dari 123 orang guru perempuan dan 58 orang guru laki-laki. Potensi sumber alam yang melimpah di Kecamatan Inuman merupakan modal untuk dapat menjadikan pembelajaran IPA di SD lebih bermakna (BPS Kuantan Singingi, 2017).

Kegiatan praktikum dalam mata pelajaran IPA di SD merupakan suatu tuntutan untuk meningkatkan hasil belajar peserta didik. Tetapi kenyataannya sebagian besar sekolah mengalami kekurangan peralatan praktikum IPA, karena itu guru dituntut dapat merancang dan mengembangkan alat praktikum IPA sederhana secara terprogram. Tentu saja tugas ini memerlukan keterampilan yang khusus, disamping ketekunan dan pengabdian yang tulus. Menurut guru, mengembangkan perangkat praktikum IPA untuk mengimplementasikan Kurikulum 2013 memerlukan pengetahuan, tenaga, waktu dan biaya yang lebih banyak (Zulhelmi, 2017). Untuk itu guru membutuhkan bimbingan pengembangan KIT IPA yang sesuai dengan tuntutan kurikulum 2013 yang berorientasi kepada keterampilan proses dan memberikan pelatihan untuk mengoperasikan KIT IPA tersebut didalam kegiatan pembelajaran.

Guna menunjang implementasi kurikulum 2013 di SD yang berbasis kompetensi dengan baik diperlukan perangkat pembelajaran yang baik dan khususnya untuk mata pelajaran IPA SD diperlukan perangkat KIT IPA, baik untuk demonstrasi atau eksperimen. Untuk mengembangkan perangkat KIT IPA SD berbasis alam sekitar diperlukan penelaahan kurikulum IPA SD dan pengetahuan yang mendalam tentang materi ajar IPA SD. Oleh karena itu, guru membutuhkan pelatihan pengembangan KIT IPA bagi sekolah yang tidak ada atau kurang lengkap KIT untuk praktikum IPA dan sekaligus memberikan pelatihan mengembangkan LKPD sesuai dengan perangkat KIT IPA yang dikembangkan serta pelatihan untuk mengoperasikan perangkat KIT untuk praktikum tersebut di dalam kelas.

Tujuan dari kegiatan pengabdian kepada masyarakat ini adalah: 1) Melatih guru-guru IPA SD di Kecamatan Inuman mengembangkan KIT IPA sederhana dengan menggunakan alat dan bahan yang ada di lingkungan sekitar sekolah untuk menunjang keterlaksanaan Kurikulum SD 2013. 2) Melatih guru-guru IPA SD di Kecamatan Inuman mengembangkan Lembaran Kerja Peserta Didik (LKPD) sebagai pedoman bagi peserta didik untuk melakukan kegiatan praktikum dari setiap perangkat praktikum yang dikembangkan. 3). Melatih guru-guru IPA SD di Kecamatan Inuman mengoperasi-kan KIT untuk praktikum yang menunjang pembelajaran IPA yang bersifat PAIKEM.

Guru memegang peranan penting dalam meningkatkan kualitas pembelajaran. Sebagai sentral dalam proses pembelajaran, guru perlu meningkatkan kualitas kegiatan belajar dan 
mengajar di sekolah. Di tingkat Sekolah Dasar, pola pikir peserta didik tentang suatu pengetahuan ditentukan sampai ke tingkat atau pendidikan yang lebih tinggi (Depdiknas, 2003). Untuk memacu kualitas para peserta didik, diperlukan kemampuan berpikir kritis. Salah satu mata pelajaran di Sekolah Dasar yang dapat mengembangkan kemampuan berpikir kritis adalah Ilmu Pengetahuan Alam (Sidharta, 1990 dalam Ilmiahilmu, 2012). Ilmu Pengetahuan Alam (IPA) merupakan mata pelajaran, yang dimaksudkan agar peserta didik mempunyai pengetahuan, gagasan dan konsep-konsep yang terorganisasi dengan alam sekitar, yang diperoleh dari pengalaman melalui serangkaian proses ilmiah, antara lain penyelidikan, penyusunan, dan penyajian gagasan-gagasan. Di dalam Ilmu Pengetahuan Alam, peserta didik dituntut memahami konsep-konsep Ilmu Pengetahuan Alam, melalui kegiatan-kegiatan dari mengamati sampai menarik simpulan, sehingga terbentuk sikap kritis dan ilmiah. Dalam kenyataan dapat terlihat bahwa proses belajar dan mengajar Ilmu Pengetahuan Alam di sekolah, banyak guru menyampaikan materi secara informatif dengan ceramah (Iskandar, 2001 dalam Ilmiahilmu, 2012).

Hasil penelitian Umar (1990) mengungkapkan bahwa tingkat penguasaan peserta didik terhadap materi Ilmu Pengetahuan Alam baru mencapai kurang dari separuh dari tuntutan kurikulum yang ideal (Ilmiahilmu, 2012). Dalam menghadapi masalah tersebut, apabila diamati dengan seksama, maka telah banyak pihak yang terkait dibidang pendidikan mencoba memecahkan persoalan rendahnya mutu pendidikan Ilmu Pengetahuan Alam. Misalnya melakukan inovasi, penataran, pelatihan, penelitian, penyediaan kurikulum. Berkaitan dengan penyediaan sarana dari pemerintah dalam hal ini Departemen Pendidikan Nasional melakukan proyek pengadaan peralatan Ilmu Pengetahuan Alam untuk Sekolah Dasar yang berupa komponen instrumen terpadu (KIT) Ilmu Pengetahuan Alam serta buku pedoman penggunaannya untuk guru.

Menurut Berta (1996), media Kit IPA adalah peralatan IPA yang diproduksi dan dikemas dalam bentuk kotak unit pengajaran, yang menyerupai rangkaian peralatan uji coba keterampilan proses pada bidang studi IPA dan dilengkapi dengan sebuah buku pedoman penggunaannya (Ilmiahilmu, 2012). Hasil penelitian Budiningsih (1994) tentang intensitas penggunaan media KIT IPA di 16 Sekolah Dasar di wilayah Kodya Yogyakarta, menunjukkan bahwa secara keseluruhan sebenarnya kelengkapan media IPA adalah cukup, namun tidak seluruhnya dimanfaatkan oleh guru. Adanya media KIT Ilmu Pengetahuan Alam diharapkan dapat memacu proses dan hasil belajar peserta didik dengan kondisi dinamis, kreatif, dan relevan dengan kehidupan sehari-hari. Namun, media KIT IPA ternyata belum dimanfaatkan oleh guru dengan optimal. Menurut Hermiati (1999), bahwa pembelajaran Ilmu Pengetahuan Alam yang selama ini dilaksanakan lebih mengandalkan olah kata, yang bersumber pada buku dan guru. Media KIT Ilmu Pengetahuan Alam yang dirancang khusus untuk mempermudah peserta didik dalam mengaitkan langsung konsep-konsep pelajaran dalam alam sekitar, ternyata hanya tampak sebagai pajangan sekolah belaka. Telah kita ketahui bersama bahwa kegiatan praktikum merupakan suatu usaha yang berharga dalam Ilmu Pengetahuan Alam, sehingga dapat memberikan rangsangan penemuan-penemuan baru dalam teknologi (Ilmiahilmu, 2012).

Penerapan Kurikulum 2013 dalam mata pelajaran IPA SD perlu perangkat praktikum yang menjadikan peserta didik mampu mendemonstrasikan pengetahuan dan keterampilan sesuai dengan standar yang ditetapkan dengan mengintegrasikan life skill (Tim Pustaka Yustisia, 2008; Depdiknas, 2006). Ini juga sejalan dengan tahap perkembangan intelektual/ kognitif anak SD, umumnya pada tahap operasional konkrit, menurut Jean Piaget sifat-sifatnya adalah berpikir konkrit karena daya otak terbatas pada objek melalui pengamatan langsung. Dapat mengembangkan operasi mental seperti menambah, mengurangi. Mulai mengembangkan struktur kognitif berupa ide atau konsep. Melakukan operasi logika dengan pola berpikir konkrit. Melakukan aktivitas yang berhubungan dengan objek dan dapat membuat keputusan logis (Depdiknas, 2004). Menurut Mel Silbermen (2011) pada saat kegiatan belajar aktif, peserta didik melakukan sebagian besar pekerjaan yang harus dilakukan. Mereka menggunakan otak mereka untuk mempelajari gagasan-gagasan, memecahkan berbagai 
masalah dan menerapkan apa yang mereka pelajari.

Karakteristik peserta didik di SD sesuai dengan tahapan proses berfikir yang bersifat kongkrit operasional yaitu: 1) pengurutan, kemampuan untuk mengurutkan objek menurut ukuran, bentuk, atau ciri lainnya. 2) klasifikasi, kemampuan untuk memberikan nama dan mengidentifikasi serangkaian benda menurut tampilannya, ukurannya, atau karakteristik lain, termasuk gagasan bahwa serangkaian benda-benda dapat menyertakan benda lainnya kedalam rangkaian tersebut. Anak tidak lagi memiliki keterbatasan logika berupa animisme (anggapan bahwa semua benda hidup dan berperasaan). 3) decentering, anak mulai mempertimbangkan beberapa aspek dari suatu permasalahan untuk bisa memecahkannya. 4) reversibility, anak mulai memahami bahwa jumlah atau bendabenda dapat diubah, kemudian kembali ke keadaan awal. 5) konservasi, memahami bahwa kuantitas, panjang, atau jumlah bendabenda adalah tidak berhubungan dengan pengaturan atau tampilan dari objek atau benda-benda tersebut. 6) penghilangan sifat egosentrisme, kemampuan untuk melihat sesuatu dari sudut pandang orang lain (bahkan saat orang tersebut berpikir dengan cara yang salah) (Homedukasi, 2013).

\section{Bahan dan Metode}

Pelaksanaan kegiatan berupa pelatihan pengebangan KIT IPA untuk guru-guru SD ini dilakukan dengan langkah-langkah yaitu:

\section{Persiapan pelatihan}

Tahap persiapan pelatihan, dilaksanakan beberapa hal diantaranya: 1) penyusunan dan penggandaan buku pedoman pelatihan pengembangan KIT IPA sederhana berbasis alam sekitar, 2) pembelian alat dan bahan yang diperlukan selama pelatihan, 3) pemberitahuan dan peminjaman tempat pelatihan, dalam hal ini adalah ruang pertemuan di Kecamatan Inuman, dan (4) Konfirmasi dan sosialisasi jadwal kepada Camat dan UPTD dinas pendidikan Kecamatan Inuman ketika Penulis sebagai DPL bagi mahasiswa Kukerta UNRI di Kecamatan Inuman pada tanggal 8 Juli 2017. Penetapan peserta dilakukan oleh UPTD dinas pendidikan Kecamatan Inuman dengan meminta masing-masing sekolah minimal mengirimkan 1 orang guru sebagai peserta pelatihan. Jumlah SD yang ikut menjadi objek pelatihan berjumlah 12 sekolah, dan total jumlah peserta pelatihan adalah 29 orang guru SD.

\section{Pelaksanaan pelatihan}

Pada tahap ini dilaksanakan pelatihan pembuatan KIT IPA sederhana berbahan dasar barang bekas bagi guru SD di Kecamatan Inuman. Kegiatan pelatihan dilaksanakan pada tanggal 12 Agustus 2017 dalam jangka waktu pelaksanaan sebanyak 4 (empat) sesi. Kegiatan pelatihan KIT IPA SD yang dilaksanakan berorientasi pada kurikulum 2013.

\section{Evaluasi hasil pelatihan}

Melalui tahap evaluasi, tim pengabdian melakukan evaluasi terhadap keseluruhan kegiatan mulai dari persiapan alat dan bahan, kegiatan pelatihan, dan respon guru-guru SD terhadap kegiatan pelatihan yang telah dilakukan. Teknik penilaian yang dilakukan adalah teknik observasi dan angket. Untuk melengkapi informasi dari guru-guru juga dilakukan wawancara. Teknik analisis data menggunakan analisis statistik deskriptif.

\section{Teknik penyelesaian masalah}

Penyelesaian masalah yang sudah diajukan pada kegiatan pengabdian ini dilakukan melalui beberapa tahap yakni:

\section{Pemodelan}

Pemodelan bertujuan memperkenalkan kepada peserta pelatihan KIT untuk praktikum IPA SD yang harus dibuat guru sebelum pelaksanaan pembelajaran IPA. KIT IPA yang diperagakan adalah contoh-contoh alat praktikum sederhana untuk materi kalor, cahaya, bunyi, listrik magnet, konsep asam basa, sistem pernapasan pada makhluk hidup, dan lain-lain.

Pemodelan yang dilakukan dalam merancang dan mengembangkan KIT IPA SD tersebut dimulai dari menelah kurikulum, kedalaman materi, analisis keadan sarana dan prasarana yang ada dan menetapkan kegiatan. Setelah semuanya siap maka baru dimulai mengembangkan KIT IPA sesuai dengan materi pokok IPA SD. 
Pembimbingan

Pembimbingan digunakan untuk melatih guru-guru membuat sendiri KIT IPA sesuai dengan materi pokok yang sudah dimodelkan dan dilanjutkan dengan melatih mengembangkan Lembaran Kerja Peserta Didik (LKPD) sebagai pedoman bagi peserta didik dalam melaksanakan kegiatan praktikum.

Pembimbingan juga digunakan untuk membimbing guru-guru mengoperasikan KIT IPA yang mereka buat sesuai dengan langkahlangkah kegiatan kerjanya yang terdapat dalam buku pedoman. Pada saat pembimbingan guruguru dibagi menjadi empat kelompok.

\section{Simulasi/ Diskusi}

Simulasi dilakukan setelah perancangan dan pengembangan KIT IPA sederhana berbasis alam sekitar selesai dilakukan. Tiap perwakilan kelompok diminta untuk mensimulasikan dengan menggunakan KIT IPA yang sudah dikembangkan.

Diskusi dilakukan sebelum dan sesudah pelaksanaan pelatihan. Diskusi yang dilakukan sebelum kegiatan diperlukan untuk mendapatkan masukan-masukan dari guru-guru tentang permasalahan yang dihadapi dalam pelaksanaan kurikulum 2013 di SD, sekaligus untuk melihat sejauhmana pengetahuan guru tentang permasalahan tersebut. Sedangkan diskusi yang dilakukan sesudah kegiatan adalah untuk mendiskusikan permasalahanpermasalahan yang ditemukan sewaktu memodelkan dan pelatihan yang berguna untuk menyelesaikan permasalahanpermasalahan yang ditemukan selama kegiatan dan untuk mendapatkan umpan balik setelah kegiatan pelatihan selesai agar dapat menentukan tindak lanjut atas kegiatan ini.

Alat ukur ketercapaian yang digunakan dalam kegiatan ini adalah dengan melalui respon peserta setelah selesai kegiatan dan juga melalui teknik observasi. Data diolah dengan menggunakan teknik persentase yaitu:

$$
\mathrm{P}=\frac{\text { skor yang diperoleh }}{\text { skor maksimum }} \times 100 \%
$$

Kriteria penentuan keberhasilan kegiatan ditentukan menurut Tabel 1.
Tabel 1. Kriteria keberhasilan pengabdian pengembangan KIT IPA SD berbasis alam sekitar

\begin{tabular}{ccl}
\hline No. & $\begin{array}{c}\text { Interval Skor } \\
\mathbf{( \% )}\end{array}$ & $\begin{array}{c}\text { Interpretasi } \\
\text { Keberhasilan } \\
\text { Pengabdian }\end{array}$ \\
\hline 1 & $0,0 \leq \mathrm{P} \leq 25$ & Sangat Tidak Baik \\
2 & $25<\mathrm{P} \leq 50$ & Tidak Baik \\
3 & $50<\mathrm{P} \leq 75$ & Baik \\
4 & $75<\mathrm{P} \leq 100$ & Sangat Baik \\
\hline
\end{tabular}

\section{Hasil dan Pembahasan}

Masyarakat sasaran dalam kegiatan pengabdian kepada masyarakat ini adalah seluruh guru-guru SD se Kecamatan Inuman Kabupaten Kuantan Singingi. Menurut Data BPS Kabupaten Kuantan Singingi (2017), jumlah guru SD yang ada adalah 181 orang. Jumlah SD baik negeri maupun swasta seluruhnya 16 sekolah dengan jumlah peserta didik 1973 orang. Pada kegiatan ini jumlah guru yang ikut adalah 29 orang (16\%), sedangkan jumlah sekolah 12 sekolah $(75 \%)$. Bila dilihat dari persentase jumlah sekolah memberikan gambaran bahwa partisipasi sekolah untuk kegiatan ini tinggi dan jika dipandang dari rasio jumlah sekolah dengan jumlah guru yang hadir menunjukkan bahwa partisipasi guru mengikuti kegiatan tinggi.

Potensi sumber daya alam yang ada di Kecamatan Inuman memberikan kemudahan untuk pembelajaran IPA karena dalam bahan kajian ilmu pengetahuan alam, antara lain, fisika, biologi, dan kimia dimaksudkan untuk mengembangkan pengetahuan, pemahaman, dan kemampuan analisis peserta didik terhadap lingkungan alam dan sekitarnya.

Pembelajaran IPA di SD memberi kesempatan untuk memupuk rasa ingin tahu siswa secara alamiah. Hal ini akan membantu siswa mengembangkan kemampuan bertanya dan mencari jawaban berdasarkan bukti serta mengembangkan cara berpikir ilmiah. IPA tidak hanya merupakan kumpulan pengetahuan atau kumpulan fakta, konsep, prinsip, atau teori semata. Tetapi IPA juga menyangkut tentang cara kerja, cara berpikir dan cara memecahkan masalah. Dalam pembelajaran IPA guru berperan sebagai wakil dari para ilmuwan untuk mengembangkan konsep- 
konsep ilmiah (science). Para ilmuwan memperoleh konsep-konsep science melalui prinsip metode ilmiah. Sikap ilmiah tersebut harus dirasakan oleh peserta didik untuk mendapatkan pelajaran yang bermakna, sehingga dapat mencapai literasi sains atau Scientific Literacy. Menurut PISA (Programe for International Student Assesment) bahwa Literacy Sains adalah kemampuan untuk menggunakan kemampuan ilmiah untuk mengidentifikasi pertanyaan-pertanyaan dan untuk menarik kesimpulan berdasarkan buktibukti agar dapat memahami dan membantu membuat keputusan tentang dunia alami dan interaksi manusia dengan alam (TOFI, 2007). Oleh karena itu, pengembangan KIT IPA bagi guru-guru SD di Kecamatan Inuman merupakan suatu tindakan yang tepat. Kegiatan yang dilakukan adalah dengan memberikan pemodelan, pembimbingan dalam pengembangan KIT IPA SD. Selanjutnya guru-guru mensimulasikan KIT IPA yang sudah dikembangkan, kemudian didiskusikan untuk memperkuat pemahaman guru guru SD se Kecamatan Inuman dalam pengembangan KIT IPA berbasis alam sekitar.

Tabel 2 Rangkuman tingkat ketercapaian kinerja guru-guru SD se Kecamatan Inuman dalam pengembangan KIT IPA

\begin{tabular}{|c|c|c|c|c|c|c|}
\hline Kelompok & $\begin{array}{c}\text { Kerjasama } \\
(\%)\end{array}$ & $\begin{array}{c}\text { Kreativitas } \\
(\%)\end{array}$ & $\begin{array}{c}\text { Keseriusan } \\
(\%)\end{array}$ & $\begin{array}{c}\text { Kualitas } \\
\text { Produk (\%) }\end{array}$ & $\begin{array}{l}\text { Rerat } \\
\text { a (\%) }\end{array}$ & Interpretasi \\
\hline I & 100 & 100 & 100 & 100 & 100 & Sangat Baik \\
\hline II & 100 & 75 & 100 & 75 & 88 & Sangat Baik \\
\hline III & 100 & 100 & 100 & 75 & 94 & Sangat Baik \\
\hline IV & 100 & 75 & 75 & 50 & 75 & Baik \\
\hline Rata-Rata & 100 & 88 & 94 & 75 & 89 & Sangat Baik \\
\hline Interpretasi & Sangat Baik & Sangat Baik & Sangat Baik & Baik & & \\
\hline
\end{tabular}

Tabel 3 Skor respon peserta terhadap kegiatan pelatihan pengembangan KIT IPA SD

\begin{tabular}{clcl}
\hline No. & \multicolumn{1}{c}{ Pernyataan } & $\begin{array}{c}\text { Rata-Rata Skor } \\
(\mathbf{\%})\end{array}$ & Interpretasi \\
\hline 1. & $\begin{array}{l}\text { Senang dengan materi pelatihan KIT } \\
\text { IPA }\end{array}$ & 98,4 & Sangat Baik \\
2. & $\begin{array}{l}\text { Berkeinginan melaksanakan pem- } \\
\text { belajaran IPA dengan KIT yang } \\
\text { memanfaatkan barang bekas }\end{array}$ & 95,3 & Sangat Baik \\
3. & $\begin{array}{l}\text { Mengajarkan IPA lebih mudah dengan } \\
\text { KIT dari bahan alam sekitar }\end{array}$ & 95,3 & Sangat Baik \\
4. & $\begin{array}{l}\text { Berkeinginan membagi pengalaman } \\
\text { dengan guru dan peserta didik tentang }\end{array}$ & 100 & Sangat Baik \\
KIT IPA dari bahan alam sekitar & & Sangat Baik \\
Berkeinginan memiliki KIT IPA dari \\
bahan alam sekitar
\end{tabular}


Berdasarkan hasil evaluasi melalui observasi yang dilakukan selama kegiatan berlangsung dan pada akhir kegiatan ini diperoleh gambaran bahwa kegiatan ini berjalan dengan baik dengan tingkat ketercapaian yang menggembirakan berdasarkan kriteria-kriteria yang sudah ditetapkan.

Tabel 2 menggambarkan bahwa ratarata tingkat ketercapaian kinerja guru-guru dalam pelatihan pengembangan KIT IPA berbasis alam sekitar adalah $89 \%$ pada kategori sangat baik. Indikator yang perlu ditingkatkan lagi adalah kualitas produk.

Di akhir kegiatan pembelajaran diberikan angket respon peserta terhadap pelaksanaan kegiatan pelatihan. Hasil analisis respon peserta secara singkat disajikan pada Tabel 3.

Data pada Tabel 3 menunjukkan bahwa rata-rata respon peserta $97,5 \%$ pada kategori sangat baik terhadap kegiatan pengabdian yang dilakukan. Hasil ini senada dengan yang dilakukan oleh Yusman Wiyatmo et al. (2017) menunjukkan bahwa: 1) peserta memiliki pengetahuan dalam merancang alat peraga, 2) peserta memiliki keterampilan dalam merancang alat peraga IPA, dan 3) peserta terampil menggunakan alat peraga IPA.

Beberapa temuan yang didapatkan setelah pelaksanaan kegiatan adalah:

1. Para peserta pelatihan tampak antusias, bersemangat dan penuh perhatian dalam mengikuti seluruh kegiatan. Meskipun ada peserta pelatihan yang tidak mengikuti kegiatan sampai akhir $(34,5$ $\%)$.

2. Para guru peserta umumnya telah mampu mengembangkan KIT IPA untuk praktikum yang dilatihkan. Para peserta merasakan bahwa waktu yang disediakan untuk melaksanakan kegiatan pelatihan ini terlalu singkat dan berharap agar kegiatan ini dilanjutkan dengan on service untuk melihat pelaksanaannya di dalam kelas.

3. Seluruh peserta menyatakan, bahwa setelah mengikuti kegiatan ini peserta memperoleh tambahan berbagai informasi, pemahaman, kemampuan, dan keterampilan yang baru tentang KIT IPA SD berbasis alam sekitar.

4. Pihak penyelenggara dan Guru-Guru menyatakan rasa puas atas penyelenggaraan kegiatan ini, serta berharap agar guru-guru SD dapat memanfaatkan alam sekitar sebagai media pembelajaran IPA serta mengoptimalkan pembelajaran IPA dengan menyelaraskan antara teori dengan praktikum.

5. Terwujudnya salah satu misi dari kegiatan ini yaitu semacam promosi program pengabdian pada masyarakat yang meliputi penerapan IPTEK kepada masyarakat guna membantu mereka dalam menghadapi permasalahan yang ada di sekolah dan sekaligus pelaksanaan salah satu darma dari tri darma perguruan tiggi.

6. Hasil wawancara kepada peserta, mereka menyatakan keinginan agak kegiatan ini dilaksanakan secara berkala.

\section{Kesimpulan dan Saran}

Analisis terhadap kegiatan program pengabdian pada masyarakat ini, dapat dinyatakan sudah berjalan dengan baik dan menunjukkan tingkat ketercapaian yang menggembirakan. Dari hasil analisis data dapat disimpulkan bahwa kegiatan pelatihan pengembangan perangkat praktikum ipa berbasis alam sekitar untuk guru-guru SD se Kecamatan Inuman Kabupaten Kuantan Singingi memberikan hasil yang sangat baik dengan tingkat ketercapaian kinerja peserta $89 \%$ pada kategori sangat baik dan respon peserta terhadap kegiatan rata-rata $97,5 \%$ pada kategori sangat baik.

Berdasarkan hasil kegiatan pengabdian kepada masyarakat yang sudah dilaksanakan dapat diberikan beberapa rekomendasi:

1. Pengembangan KIT IPA di SD hendaklah lebih dioptimalkan, karena penanaman konsep IPA lebih baik melalui pendekatan saintifik. Jika para guru kurang mampu hendaklah pihak sekolah pro aktif berupaya menjalin kerja sama dengan perguruan tinggi terkait untuk memberikan pelatihan.

2. Pelaksanaan pengabdian ini sebaiknya dilanjutkan dengan kegiatan on service, agar apa yang didapatkan selama pelatihan bisa terlihat implementasinya langsung di lapangan dan sekaligus bisa 
pula dilakukan penelitian tindakan kelas oleh guru yang bersangkutan.

\section{Daftar Pustaka}

BPS Kuantan Singingi, 2017. Kecamatan Inuman dalam Angka 2017. https://kuansingkab.bps.go.id/frontend/i ndex.php/publikasi. (Dikunjungi 8 Desember 2017).

Budiningsih, 1994. Intensitas Penggunaan Media KIT IPA di 16 Sekolah Dasar di Wilayah Kodya UNY, Yogyakarta.

Depdiknas, 2006. Standar Kompetensi Mata Pelajaran Sains SD dan MI. Jakarta.

Depdiknas, 2004. Sains. Buku ke-4, Jakarta.

Depdiknas, 2003. Undang-Undang RI Nomor 20 Tahun 2003 tentang Sistem Pendidikan Normal, Jakarta.

Home Edukasi, 2013. Pembelajaran IPA di SD http://www.homedukasi.com. Dikunjungi 7 Maret 2015.

Ilmiahilmu, 2012. Penggunaan Media Kit IPA dalam Menunjang Proses Pembelajaran
IPA di Sekolah Dasar Daerah Binaan IV Kecamatan Petarukan Pemalang. https://ilmiahilmu.wordpress.com. dikunjungi 10 Desember 2017.

Mel Silberman, 2011. Active Learning (Terjemahan).Yappendis, Yogyakarta.

Tim Pustaka Yustisia, 2008. Panduan Lengkap KTSP.

TOFI, 2007. WOMS (Wokkshop Olimpiade Matematika \& Sains. Mutendik, Pemda SI/LPFI, Tim TOFI, Jakarta.

Yusman Wiyatmo et al., 2017. Pelatihan Pembuatan Media Pembelajaran IPA Sederhana Bagi Guru IPA SD di Kabupaten Sleman. Jurnal Pengabdian Masyarakat MIPA dan Pendidikan $M I P A$, Volume 1 (1), 41-45. Dikunjungi 9 Desember 2017.

Zulhelmi, 2013. Pengembangan Perangkat Laboratorium Mini Fisika SMP Materi Pokok Geometrik (Cahaya) Ber orientasi Pendekatan Keterampilan Proses, Laporan Penelitian. 